\title{
THE STUDY OF AMINO ACID COMPOSITION OF SAPROPEL BY THE CAPILLARY ELECTROPHORESIS METHOD
}

\author{
O.Ye.Strus \\ Danylo Halytsky Lviv National Medical University \\ Key words: sapropel; capillary electrophoresis method; amino acid composition
}

\begin{abstract}
A diverse composition of sapropels allows to use them successfully in cosmetology. Sapropelic therapeutic muds exhibit the anti-inflammatory and desensitizing effect, protect the body from the damaging effects of free radicals, slow down the aging processes, give the skin freshness and elasticity, improve the cell regeneration by $10 \%$, moisturize and increase elasticity and thickness of the keratoid layer of the epidermis. A wide range of indications for using sapropels demonstrates the importance of their application for prevention and treatment of diseases, and the relevance and prospects for their further studies to obtain new pharmaceuticals and cosmetics. When conducting research by the capillary electrophoresis method the "Kapel'-105/105 M" system with a positive polarity of a high voltage source (the internal diameter of the capillary is $50 \mu \mathrm{m}$, the full length of the capillary is $75 \mathrm{~cm}$, the effective length is $65 \mathrm{~cm}$ ) equipped with a special software for personal computers was applied. The amino acid composition of sapropel from Prybych deposits (Shatsky district, Volyn region) has been studied. The presence of a number of amino acids in sapropel with the total content of more than $2 \%$ has been found using capillary electrophoresis. Sapropel contains a vast amount of essential amino acids (histidine, isoleucine, leucine, lysine, methionine, phenylalanine, threonine, tryptophan and valine) and a number of nonessential ones (alanine, arginine, glycine, proline and serine). Alanine, glycine, leucine, and isoleucine prevail in the mixture analyzed.
\end{abstract}

It is known that the treatment by sapropel improves lymph and blood circulation, strengthens the vascular wall and stimulates the function of the autonomic nervous system. Sapropel stimulates metabolism in tissues, increases the oxygen exchange, has a tonic effect and pronounced antibacterial action, promotes activation of immune reactions, increases the body's resistance to diseases, successfully controls the pathogenic microflora of the mucous membranes, eliminates inflammation without damaging of the useful microflora, etc. [3, 4].

A diverse composition of sapropels allows to use them successfully in cosmetology. Sapropelic therapeutic muds exhibit anti-inflammatory and desensitizing effect, protect the body from the damaging effects of free radicals, slow down the aging processes, give the skin freshness and elasticity, improve the cell regeneration by $10 \%$, moisturize and increase elasticity and thickness of the keratoid layer of the epidermis [4].

A wide range of indications for using sapropels demonstrates the importance of their application for prevention and treatment of diseases, and the relevance and prospects for their further studies to obtain new pharmaceuticals and cosmetics.

The aim of the study was to investigate the amino acid composition of sapropel of Prybych deposits (Shatsky district, Volyn region).

Materials and Methods

The study of anhydrous sapropel of Prybych deposits (Shatsky district, Volyn region) was carried out in the Laboratory of Feed Additives and Premixtures Control at the State Scientific-Research Control Institute of Veterinary Medicinal Products and Feed Additives in Lviv.
Currently for determination of amino acids chemical methods of research, the method of high performance liquid chromatography are used, as well as the method for separation of complex mixtures - capillary electrophoresis, which allows analyzing ionic and neutral components of various origin with a high efficiency; its application has increased within the last two decades $[1,11,12]$.

Traditionally, capillary electrophoresis is compared with high performance liquid chromatography since in both methods separation takes place in a confined space (capillary or column) involving the mobile liquid phase (buffer or eluent), and for registration of signals the similar principles for detection and software data processing are applied $[5,9,10]$.

The advantages of the capillary electrophoresis method are high efficiency of the sample separation; small amounts of the samples to be analyzed, buffers, highly pure and expensive organic solvents; the absence of columns and sorbents; short-term investigation periods $[6,7,8]$.

The capillary electrophoresis method has been successfully applied for analysis of various substances (inorganic and organic cations and anions, amino acids, vitamins, dyes, proteins, etc.) and also for process control of production, incoming inspection of the raw material, analysis of pharmaceuticals and food products, in forensics, medicine, biochemistry, etc. [2].

The method is based on decomposition of the samples with acidic hydrolysis of amino acids into free forms of phenylisothiocarbamide derivatives (PTC-derivatives), their subsequent separation and quantitative determination by capillary electrophoresis. 


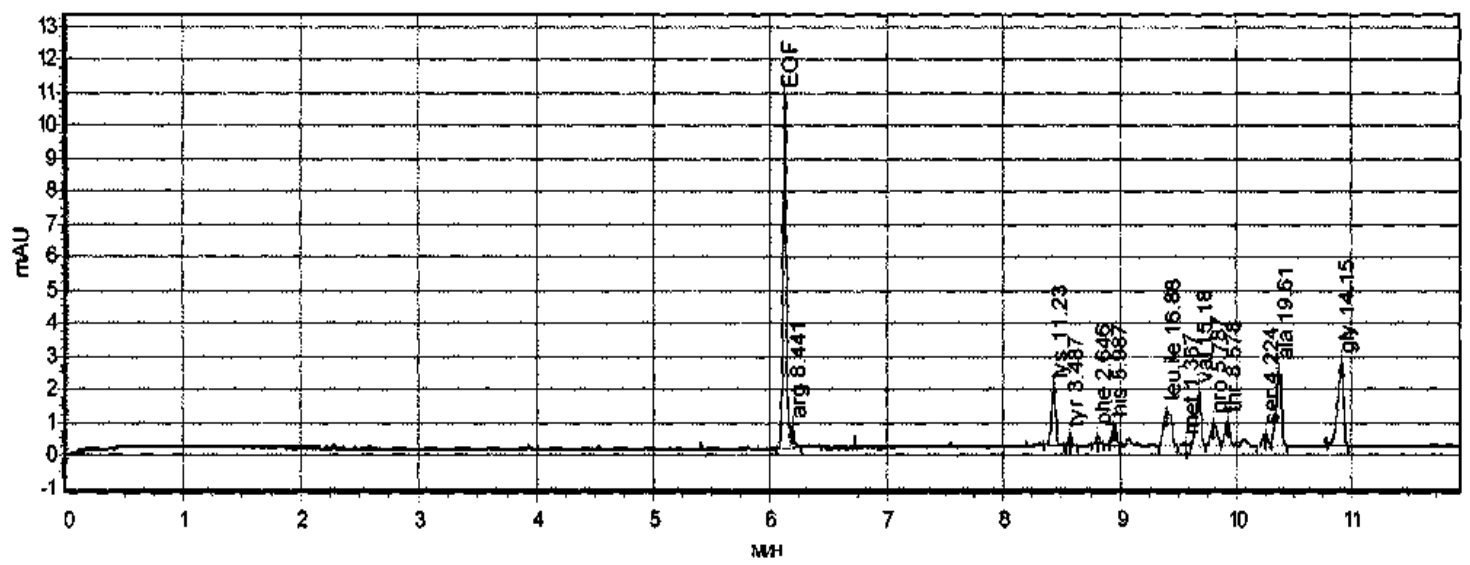

Fig. 1. The electrophoregram of acid hydrolysate of the test sample of sapropel No.1 (amino acids in the order of peaks: arginine, lysine, tyrosine, phenylalanine, histidine, leucine + isoleucine, methionine, valine, proline, threonine, serine, alanine, glycine).

In accordance with the guidelines of "Feed and feed raw material. Determination of amino acids by capillary electrophoresis using the capillary electrophoresis system "Kapel' - 105/105m" the method for determination of the mass fraction of such amino acids as arginine, lysine, tyrosine, phenylalanine, histidine, leucine and isoleucine (total), methionine, valine, proline, threonine, serine, alanine, and glycine was developed.

When conducting research by the capillary electrophoresis method the "Kapel' - 105/105 M" system with a positive polarity of a high voltage source (the internal diameter of the capillary is $50 \mu \mathrm{m}$, the full length of the capillary is $75 \mathrm{~cm}$, the effective length is $65 \mathrm{~cm}$ ) equipped with a special software for personal computers was applied.

When preparing for measurement the sampling, preparation of the capillary and calibrated solutions to work, calibration of "Kapel" system capillary electrophoresis and sample preparation were carried out.

The starting materials for preparing calibrated solutions are preparations of L-isomer of amino acids of guarantee purity (the content of the mass fraction of the active substance is at least $98 \%$ ).

Performance of tests included the following successive stages: hydrolysis of samples, obtaining of PTCderivatives of amino acids and analysis of the samples prepared.

Hydrolysis of samples. Place $100.0 \pm 0.2 \mathrm{mg}$ of the weighed sample into a hydrolysis vial, add $10 \mathrm{~cm}^{3}$ of hydrochloric acid, seal and mix. Place the vial in the drying cabinet. Carry out hydrolysis at the temperature of $110^{\circ} \mathrm{C}$ for $14-16$ hours. Remove vials with the samples from the drying cabinet after hydrolysis and cool to the room temperature. Cool and filter the content of vials through a "blue ribbon filter", reject the first portions and collect basic filtrates in a bowl with a lid to prevent evaporation. Then proceed to obtain PTC-derivatives.

Obtaining of PTC-derivatives of amino acids. Add $0.05 \mathrm{~cm}^{3}$ of the sample hydrolysates into $10-15 \mathrm{~cm}^{3}$ glass cups. Evaporate the solutions to dryness in the flow of warm air. Add $0.15 \mathrm{~cm}^{3}$ of sodium carbonate solution,
$0.3 \mathrm{~cm}^{3}$ of phenyl isothioacetate (PTA) solution into each bottle with a dry residue. Thoroughly stir to dissolve the precipitate, close the lid and leave for $35 \mathrm{~min}$ at the room temperature. Then evaporate the solution to dryness in the flow of warm air.

Analysis of the samples prepared. Transfer solutions prepared for the analysis to Eppendorf test tubes, centrifuge for 1 minute at a speed of $6000 \mathrm{rev} / \mathrm{min}$.

Record at least two electrophoregrams for each solution prepared in the appropriate conditions. Check the accuracy of the automatic marking of peaks after analysis. Using the software, conduct identification of the components in the sample comparing retention times of the components in the sample analyzed and the control mixture without exceeding the identification width more than $5 \%$.

Processing of the test results. The mass fraction of each amino acid (X, \%) was calculated by the formula:

$$
\mathrm{X}=\frac{10 \cdot \mathrm{C}_{\mathrm{vis}}}{m} \text {, }
$$

where: $\mathrm{C}_{\mathrm{vis}}$ - is the value of the mass concentration of amino acid determined in solution, $\mathrm{mg} / \mathrm{dm}^{3} ; m$ - is mass of the weighed sample, mg.

In parallel, two studies were performed. Record two electrophoregrams for each of the solutions prepared. The conditions of the study were the weighed sample of sapropel No.1-509.4 mg, sample No.2-300.1 mg, temperature $-30.0^{\circ} \mathrm{C}$, the wavelength $-254 \mathrm{~nm}$.

\section{Results and Discussion}

Electrophoregrams and the results of quantitative determination of amino acids are shown in Fig. 1, Fig. 2 and Tab. 1.

The results of the study are presented in Tab. 2 and show that sapropel contains essential amino acids (histidine, isoleucine, leucine, lysine, methionine, phenylalanine, threonine, tryptophan and valine) and a number of nonessential amino acids (alanine, arginine, glycine, proline and serine), their total content is about $2 \%$.

Alanine, glycine, leucine and isoleucine, and small amounts of serine, tyrosine, phenylalanine and methionine predominate in the mixture of amino acids studied. 


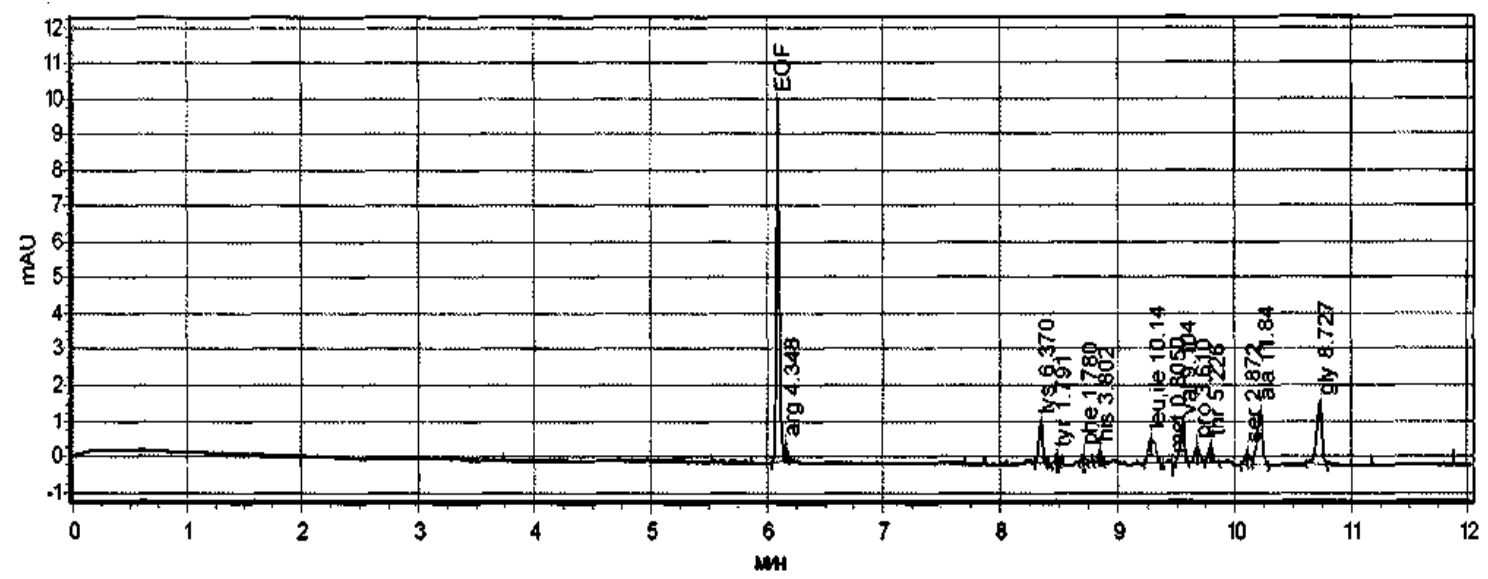

Fig. 2. The electrophoregram of acid hydrolysate of the test sample of sapropel No.2 (amino acids in the order of peaks: arginine, lysine, tyrosine, phenylalanine, histidine, leucine + isoleucine, methionine, valine, proline, threonine, serine, alanine, glycine)

Table 1

The results of quantitative determination of amino acids

\begin{tabular}{|l|c|c|c|c|c|c|}
\hline \multicolumn{1}{|c|}{ Amino acid } & $\begin{array}{c}\text { Retention } \\
\text { time, } \\
\text { sample 1, min }\end{array}$ & $\begin{array}{c}\text { Peak area, } \\
\text { sample 1, } \mathrm{cm}^{2}\end{array}$ & $\begin{array}{c}\text { Concentration, } \\
\text { sample 1, } \\
\mathrm{mg} / \mathrm{l}, \mathrm{C}_{\text {vis }}\end{array}$ & $\begin{array}{c}\text { Retention } \\
\text { time, } \\
\text { sample 2, min }\end{array}$ & $\begin{array}{c}\text { Peak area, } \\
\text { sample 2, } \mathrm{cm}^{2}\end{array}$ & $\begin{array}{c}\text { Concentration, } \\
\text { sample 2, } \\
\mathrm{mg} / \mathrm{l}, \mathrm{C}_{\text {vis }}\end{array}$ \\
\hline EOF & 6.123 & 200.4 & & 6.093 & 185.1 & \\
\hline Arginine & 6.192 & 12.24 & 8.441 & 6.160 & 6.308 & 4.348 \\
\hline Lysine & 8.433 & 44.40 & 11.23 & 8.352 & 25.18 & 6.370 \\
\hline Tyrosine & 8.575 & 8.254 & 3.487 & 8.490 & 4.238 & 1.791 \\
\hline Phenylalanine & 8.810 & 6.174 & 2.646 & 8.718 & 4.155 & 1.780 \\
\hline Histidine & 8.948 & 13.65 & 5.987 & 8.852 & 8.670 & 3.802 \\
\hline Leucine + isoleucine & 9.400 & 52.27 & 16.88 & 9.292 & 31.40 & 10.14 \\
\hline Methionine & 9.558 & 3.654 & 1.367 & 9.463 & 2.151 & 0.8050 \\
\hline Valine & 9.678 & 48.39 & 15.18 & 9.553 & 29.02 & 9.104 \\
\hline Proline & 9.803 & 25.93 & 5.787 & 9.678 & 16.17 & 3.610 \\
\hline Threonine & 9.923 & 22.72 & 8.578 & 9.793 & 13.84 & 5.226 \\
\hline Serine & 10.248 & 13.71 & 4.224 & 10.107 & 9.324 & 2.872 \\
\hline Alanine & 10.372 & 79.19 & 19.61 & 10.218 & 47.82 & 11.84 \\
\hline Glycine & 10.908 & 87.12 & 14.15 & 10.732 & 53.73 & 8.727 \\
\hline
\end{tabular}

Table 2

The quantitative analysis of amino acids in sapropel of Prybych deposits

$$
\mathrm{X} \pm \Delta, \%, \mathrm{P}=0.95, \mathrm{n}=2
$$

\begin{tabular}{|l|c|c|c|c|c|c|}
\hline \multicolumn{1}{|c|}{ Amino acid } & $\begin{array}{c}\text { Sample No.1 } \\
\mathrm{X}, \%\end{array}$ & $\pm \Delta, \%$ & $\pm \delta, \%$ & $\begin{array}{c}\text { Sample No.2 } \\
\mathrm{X}, \%\end{array}$ & $\pm \Delta, \%$ & $\pm \delta, \%$ \\
\hline Arginine & 0.14 & 0.06 & 40 & 0.16 & 0.06 & 40 \\
\hline Lysine & 0.21 & 0.07 & 34 & 0.22 & 0.07 & 34 \\
\hline Tyrosine & 0.06 & 0.02 & 30 & 0.07 & 0.02 & 30 \\
\hline Phenylalanine & 0.06 & 0.02 & 30 & 0.05 & 0.02 & 30 \\
\hline Histidine & 0.13 & 0.07 & 50 & 0.12 & 0.06 & 50 \\
\hline leucine and isoleucine & 0.34 & 0.09 & 26 & 0.33 & 0.07 & 26 \\
\hline Methionine & 0.03 & 0.01 & 34 & 0.03 & 0.01 & 34 \\
\hline Valine & 0.3 & 0.12 & 40 & 0.3 & 0.12 & 40 \\
\hline Proline & 0.12 & 0.03 & 26 & 0.11 & 0.03 & 26 \\
\hline Threonine & 0.17 & 0.07 & 40 & 0.17 & 0.07 & 40 \\
\hline Serine & 0.09 & 0.02 & 26 & 0.08 & 0.02 & 26 \\
\hline Alanine & 0.39 & 0.10 & 26 & 0.38 & 0.09 & 26 \\
\hline Glycine & 0.29 & 0.09 & 34 & 0.28 & 0.09 & 34 \\
\hline
\end{tabular}




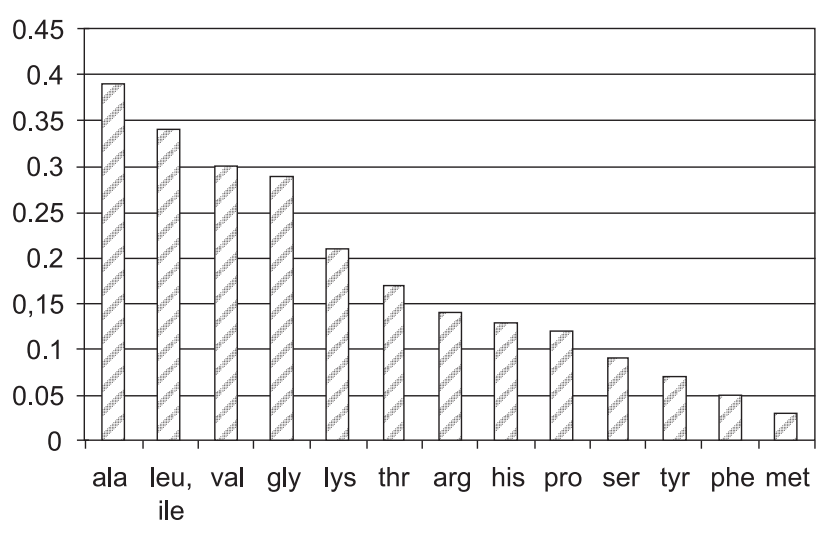

Fig. 3. The amino acids content in the sapropel samples analyzed.
The amino acids that are present in the mixture and their quantitative content (in \%) are shown in Fig. 3.

CONCLUSIONS

1. The amino acid composition of sapropel from the Prybych lake deposits (Shatsky district, Volyn region) has been investigated. The presence of a number of essential and nonessential amino acids in sapropel with the total content of more than $2 \%$ has been found using capillary electrophoresis.

2. Sapropel contains a vast amount of essential amino acids (histidine, isoleucine, leucine, lysine, methionine, phenylalanine, threonine, tryptophan and valine) and a number of nonessential ones (alanine, arginine, glycine, proline and serine). Alanine, glycine, leucine, and isoleucine prevail in the mixture.

\section{REFERENCES}

1. Каменцев Я.С., Комарова Н.В. // Аналитика и контроль. - 2002. - Т. 6, №1. - С. 13-18.

2. Корми та кормова сировина. Визначення вмісту амінокислот методом капілярного електрофорезу з використанням системи капілярного електрофорезу «Капель-105/105М»: Метод. рекоменд. / Державний науково-дослідний контрольний інститут ветеринарних препаратів та кормових добавок. - Львів, 2013. -47 c.

3. Куликов В.Ю. Адаптогенные и лечебные свойства пелоидов. - Новосибирск, 2001. - 219 с.

4. Струс О.С. // Укр. журн. клін. та лабораторної медицини. - 2014. - T. 9, №2. - С. 56-62.

5. Balammal G., Sekar B.M., Jayachandra R.P. // Intern. J. of Preclinical and Pharmac. Res. - 2012. - Vol. 3, Issue 1. - P. 50-63.

6. Brkljaca R., Urban S. // J. Liq. Chrom. Rel. Technol. - 2011. - Vol. 34. - P. 1063-1076.

7. Cordell G.A., Shin Y.G. // Pure Appl. Chem. - 1999. - Vol. 71. - P. 1089-1094.

8. Lambert M., Wolfender J.L., Staerk D. et al. // Anal. Chem. - 2007. - Vol. 379. - P. 727-735.

9. Lang G., Mayhudin N.A., Mitova M.I. et al. // J. Nat. Prod. - 2008. - Vol. 19. - P. 1595-1599.

10. Lewis R.J., Bernstein M.A., Duncan S.J., Sleigh C.J. // Magn. Reson. Chem. -2005. - Vol. 43. - P. 783-789.

11. Soga T. // Methods Mol. Biol. - 2007. - Vol. 358. - P. 129-137.

12. Sun Lin J., Mahyudin N.A., Chamyuang S. et al. // Proceedings of Manapro XII: 12th Intern. Symposium of Marine Natural Products, Feb 4th-9th, 2007, Queenstown, New Zealand. - Queenstown, 2007. - P. 130-138.

\section{ДОСЛІДЖЕННЯ АМІНОКИСЛОТНОГО СКЛАДУ САПРОПЕЛЮ МЕТОДОМ КАПІЛЯРНОГО ЕЛЕКТРОФОРЕЗУ \\ O.€.Cmpyc \\ Ключові слова: сапропель; метод капілярного електрофорезу; амінокислотний склад}

Різноманітний склад сапропелів дозволяє успішно використовувати їх у косметології. Грязі лікувальні сапропелеві володіють протизапальною та десенсибілізуючою дією, захищають організм від руйнівної дії вільних радикалів, сповільнюючи процеси старіння, надають шкірі свіжості, пружності та еластичності, покращують клітинну регенерацію на 10\%, зволожують та збільшують товщину і еластичність рогового шару епідермісу. Широкий спектр показань для використання сапропелів переконливо демонструє значимість їх використання у профрілактиці та лікуванні захворювань, а також актуальність та перспективність їх подальшого дослідження з метою отримання нових лікарських та косметичних засобів. При проведенні досліджень методом капілярного електрофорезу використовували систему капілярного електрофорезу «Капель - 105/105 М» із позитивною полярністю джерела високої напруги (внутрішній діаметр капіляра 50 мкм, повна довжина капіляра - 75 см, ефрективна довжина - 65 см), оснащену спеціальним програмним забезпеченням на основі персонального комп'ютера. Досліджено амінокислотний склад сапропелю родовища озера Прибич Шацького району Волинської області. Встановлено наявність у складі сапропелю низки амінокислот, сумарний вміст яких перевищує 2\%. Сапропель містить переважну кількість незамінних амінокислот (әістидин, ізолейцин, лейцин, лізин, метіонін, френілаланін, треонін, триптофран і валін ) і ряд замінних (аланін, аргінін, гліцин, пролін і серин) амінокислот. У суміші переважають аланін, гліцин, лейцин та ізолейцин. 


\section{ИССЛЕДОВАНИЕ АМИНОКИСЛОТНОГО СОСТАВА САПРОПЕЛЯ МЕТОДОМ КАПИЛЛЯРНОГО ЭЛЕКТРОФОРЕЗА \\ O.E.Cmpyc \\ Ключевые слова: сапропель; метод капиллярного электрофоореза; аминокислотный состав}

Разнообразный состав сапропелей позволяет успешно использовать их в косметологии. Грязи лечебные сапропелевые обладают противовоспалительным и десенсибилизирующим действием, защищают организм от разрушительного воздействия свободных радикалов, замедляя процессы старения, придают коже свежесть, упругость и эластичность, улучшают клеточную регенерацию на 10\%, увлажняют и увеличивают толщину и эластичность рогового слоя эпидермиса. Широкий спектр показаний для использования сапропелей убедительно демонстрирует значимость их использования в профилактике и лечении заболеваний, а также актуальность и перспективность их дальнейшего исследования с целью получения новых лекарственных средств. При проведении исследований методом капиллярного электрофореза использовали систему капиллярного электрофореза «Капель - 105/105 М» с положительной полярностью источника высокого напряжения (внутренний диаметр капилляра - 50 мкм, полная длина капилляра - 75 см, эфрфективная длина - 65 см), оснащенную специальным программным обеспечением на основе персонального компьютера. Исследован аминокислотный состав сапропеля месторождения озера Прибич Шацкого района Волынской области. Установлено наличие в составе сапропеля ряда аминокислот, суммарное содержание которых превышает 2\%. Сапропель содержит подавляющее количество незаменимых аминокислот (гистидин, изолейцин, лейцин, лизин, метионин, фенилаланин, треонин, триптофран и валин) и ряд заменимых (аланин, аргинин, глицин, пролин и серин) аминокислот. В смеси преобладают аланин, глицин, лейцин и изолейцин. 